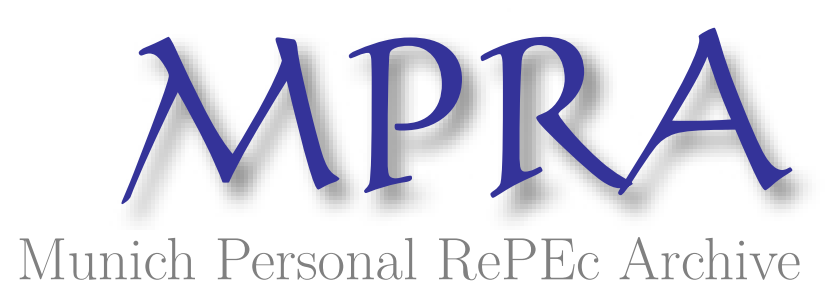

\title{
Microfinance Models: Lessons Learned
}

Ozili, Peterson K

21 November 2018

Online at https://mpra.ub.uni-muenchen.de/90221/

MPRA Paper No. 90221, posted 25 Nov 2018 21:42 UTC 


\title{
Microfinance Models: Lessons Learned
}

\author{
Peterson K. Ozili
}

\begin{abstract}
Microfinance is crucial to accelerate economic growth in a country, and is also important for financial inclusion. This article is a concise brief on some microfinance delivery models with the aim to identify some lesson learned. Microfinance offers positive prospects for stronger development finance. The support of the government should be sustained and the model of microfinance delivery model should be reviewed from time to time.
\end{abstract}

November, 2018.

This is an article for the Nigerian Microfinance Newsletter, $24^{\text {th }}$ edition, a publication of the Development Finance Department, Central Bank of Nigeria, Abuja. 


\section{Introduction}

Microfinance is one of the most notable innovations in finance (Robinson, 2001). Microfinance is crucial for poverty reduction particularly for individuals, and it accelerates economic activity in rural communities around the world. In Nigeria, the most important benefit of microfinance is that it makes funds available to poor individuals for consumption, savings and investment purposes particularly in poverty-stricken communities, and it helps small businesses to carry out economic activities.

Microfinance in Nigeria has received a major boost through multiple direct and indirect government interventions through various government agencies such as the Central Bank of Nigeria, the Bank of Industry, Small and Medium Enterprises Development Agency of Nigeria, among others. Also, digital finance has aided the smooth flow of funds from urban areas to rural communities without the need to visit a banking hall (Ozili, 2018). As a result, many poor individuals have been brought into the formal financial services sector. The CBN's development finance initiatives have also been crucial to support microfinance funding in the country $(C B N, 2012)^{1}$. The Bank has done a lot more in putting money into the hands of poor families and to empower women financially.

Globally, there are still debates on what constitute the best model of microfinance delivery around the world. There are also debates in favour of government intervention in microfinancing, suggesting that microfinance cannot be sustained without government support. Assuming there is no direct government intervention in the microfinance sector, it is doubtful that microfinance can be sustained without government support or without the support of foreign governments.

In Nigeria, microfinance delivery is currently achieved through licensed microfinance banks, and through the offering of specialized loans for entrepreneurial and agricultural projects through the Central Bank's lending window to small business owners, individuals and other micro-borrowers. In this article, I explore some options and identify some lesson learnt. This article will discuss microfinance and the various delivery models for microfinance, to identify the lesson learned.

1 https://www.cbn.gov.ng/out/2013/ccd/amended\%20regulatory\%20and\%20supervisory\%20guidelines\%20for\%20 $\underline{\mathrm{mfb}} . \mathrm{pdf}$ 


\section{Some Examples}

India: India adopts the 'small finance bank' model of microfinancing. Prior to 2014, India adopted the traditional model of microfinance delivery which is commonly achieved through microfinance banks (Yaron et al, 2018). During this period, many Indian microfinance customers had become overburdened with debt, and over time, the sector collapsed. In 2015, the Reserve Bank of India (RBI) replaced its microfinance model, imposed stricter lending parameters and introduced greater oversight over microfinance institutions. The RBI replaced the old model with the 'small finance bank' model. Banks with a 'small-finance bank' license can provide the basic banking service of accepting deposit and lending. The goal of this model is to provide financial inclusion to parts of the economy not being served by other banks such as small business units, small farmers, etc. So far, this new model is working well in India.

China: China adopts the tripartite model of microfinancing. In china, microfinance delivery is achieved through three parties - the government, non-governmental organizations (NGOs) and commercial banks (not microfinance banks). The government give loans to poor individuals and to other small borrowers through its public banks, even though the prospects for loan repayment is doubtful. Also, Chinese commercial banks only lend to small borrowers who are credit worthy. Customers who are not creditworthy to obtain loan from commercial banks can obtain funding from humanitarian nongovernmental organizations (NGOs), many of whom are funded by generous corporate and individual philanthropists. $^{2}$

\section{Lessons Learnt}

From the two models discussed above, there are two important lessons to be learned. Firstly, microfinance can work better for the poor if funds are delivered directly to the poor without the use of many intermediaries. Using multiple intermediaries to deliver microfinance may give rise to high administration costs, poor credit screening standards, among others. Secondly, it can be difficult to enforce microfinance loan repayments from individuals in poor communities particularly when such loans are issued through public banks. From hindsight we know that the rate of micro-loan repayment is usually low in countries where microfinance is delivered through public banks, and this

\footnotetext{
${ }^{2}$ http://knowledge.wharton.upenn.edu/article/microfinance-in-china-growth-and-struggle/
} 
was what imploded the Indian microfinance sector in 2014. In fact, the biggest problem of microfinance delivered through public banks is that borrowers are often unwilling to repay their debt because they believe public banks are government-owned banks and that the loan given to them is their own fair share of their citizen entitlement. Eventually, such loans end up as non-performing loans in the accounts of banks when borrowers refuse to repay.

\section{Recommendations}

Going forward, there are two recommendations. First, the microfinance model adopted in a country should reflect the peculiarity of the country, the location of its poorest communities, and the ability of lenders to reach borrowers in remote communities who are financially excluded. This is because microfinance can work better for the poor if funds are delivered directly to the poor without the use of many intermediaries. Secondly, a microfinance model should have a well-designed loan repayment plan. A well-designed plan on how small borrowers should repay the micro-loans issued to them in a timely manner, is needed. This will ensure that microfinancing is sustainable in the long-run. Thirdly, Nigeria's microfinance model is working well but it is not without challenges. Notwithstanding its challenges, the current microfinance delivery model in Nigeria should be more flexible to changing population size and economic needs.

\section{Conclusion}

Microfinancing is crucial to accelerate economic activity in any economy and the model of microfinance delivery is equally important for sustainable microfinancing. This article explored some microfinance delivery models with the aim to identify some lesson learned. Going forward, there are positive prospects for stronger development finance in Nigeria through sustainable microfinance. The support of the government should be sustained and Nigeria's microfinance delivery model should be reviewed from time to time 


\section{Reference}

Cbn (2012). Revised Regulatory And Supervisory Guidelines For Microfinance Banks (Mfbs) In Nigeria https://www.cbn.gov.ng/out/2013/ccd/amended\%20regulatory\%20and\%20supervisory\%20guideline s\%20for\%20mfb.pdf

Ozili, P. K. (2018). Impact of digital finance on financial inclusion and stability. Borsa Istanbul Review.

Robinson, M. S. (2001). The microfinance revolution: Sustainable finance for the poor. The World Bank.

Yaron, G., Gordon, R., Best, J., \& Choudhary, S. (2018). Microfinance for the marginalized: the impact of the Rojiroti approach in India. Enterprise Development and Microfinance, 29(1), 80-93. 